\title{
Mineral Resources of the
}

\section{San Rafael Primitive Area}

\section{California}

GEOLOGICAL SURVEY BULLETIN $1230-A$ 



\section{Mineral Resources of the}

San Rafael Primitive Area

\section{California}

By H. D. GOWER, J. G. VEDDER, H. E. CLIFTON, and E. V. POST

STUDIES RELATED TO WILDERNESS

GE OL O G C A L S UR V E Y B ULLE T I N $1230-$ A

Description of an area at the

southern end of the Coast Ranges

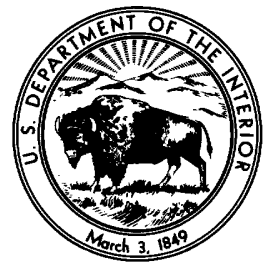


UNITED STATES DEPARTMENT OF THE INTERIOR

STEWART L. UDALL, Secretary

\section{GEOLOGICAL SURVEY}

William T. Pecora, Director 


\section{STUDIES RELATED TO WII.DERNE.SS}

The Wilderness Act (Public Law 88-577, Sept. 3, 1964) and the Conference Report on Senate bill 4, 88th Congress, direct the U.S. Geological Survey and the U.S. Bureau of Mines to make mineral surveys of wilderness and primitive areas. Areas officially designated as "wilderness," "wild," or "canoe," when the act was passed, were incorporated into the National Wilderness Preservation System. Areas classed as "primitive" were not included in the Wilderness System, but the act provided that each primitive area should be studied for its suitability for incorporation into the Wilderness System. The mineral surveys constitute one aspect of the suitability studies. This bulletin reports the results of a mineral survey in the San Rafael primitive area, California. The area discussed in the report corresponds to the area under consideration for wilderness status. It is not identical with the San Rafael Primitive Area as defined because modifications of the boundary have been proposed for the area to be considered for wilderness status. The area that was studied is referred to in this report as the San Rafael primitive area.

This bulletin is the first of a series of similar reports on primitive areas. 



\section{CONTENTS}

Page

Summary

Introduction

Purpose and scope

Location and accessibility

Topography and vegetation 3

Previous work

Fieldwork and methods of study

General geology

Stratigraphy

Cretaceous rocks

Tertiary rocks

Eocene rocks

Miocene rocks

Intrusive igneous rocks

Pleistocene and Recent deposits...._. 12

Structure

Folds

Faults

Mineral resources

Setting

Mercury _._. 17

Petroleum

Limestone

Other commodities investigated

References cited

\section{ILLUSTRATIONS}

Plate 1. Reconnaissance geologic map of the San Rafael primitive area

2. Geochemical sample-locality map

FIGURE 1. Index map of California

2. Index map of primitive area

3. Photograph of Cretaceous sandstone cliffs

4. Photograph showing north side of Hurricane Deck

5. Map showing location of geologic traverses_______._. 7

6. Photograph showing unconformity between Miocene and Eocene rocks_. 11

7. Photograph showing Nacimiento(?) fault__.___________ 14

8. Map showing oil and gas fields of southern California____- 22 


\section{TABLES}

TABLE 1. Geochemical analyses ___ A19

2. Mercury content of rocks _.____ 21

3. Partial analysis of Sierra Blanca Limestone of Nelson (1925) _... 25

4. Base-metal content of stream sediment 


\title{
STUDIES RELATED TO WILDERNESS
}

\section{MINERAL RESOURGES OF THE SAN RAFAEL PRIMITIVE AREA, CALIFORNIA}

\author{
By H. D. Gower, J. G. Vedder, H. E. Glifton, ANd E. V. Post \\ SUMMARY
}

The San Rafael primitive area lies at the southern end of the Coast Ranges of California. Although several important mineral commodities are produced from this general region, no mineral deposits approaching commercial grade were recognized within the primitive area by the investigations of the U.S. Geological Survey. Five mineral claims have been located, but no minerals have been produced from the area. No oil test holes have been drilled within the area; several holes drilled only 2 or 3 miles from the northern and southern borders were not productive.

The San Rafael primitive area is underlain by about 22,000 feet of moderately to intensely faulted and folded sedimentary rocks of Late Cretaceous and Tertiary age. These rocks are mainly sandstone, conglomerate, siltstone, and shale, but they also include minor amounts of limestone. The only igneous rocks in the area are two small diabase intrusions.

The primitive area is flanked on three sides at distances of several miles by producing oil fields and is bordered on the southwest by the once-productive Cachuma quicksilver (mercury) district. Nearly all the petroleum production from nearby oil fields has come from rocks of Miocene and Pliocene age. About 25 percent of the primitive area is underlain by rocks of Miocene age, but the rocks lack suitable trap structures, except on a relatively small scale. The quicksilver deposits in the Cachuma district occur with quartz and carbonate minerals in sheared shales of Late Jurassic to Early Cretaceous age, which do not crop out in the primitive area. However, a weak mercury anomaly was discovered by geochemical exploration in Sulphur Spring Canyon near the southern border of the area. The mercury content of the richest rocks sampled is only about one-thousandth of that required for commercial exploitation, and the probability of a major deposit of quicksilver at depth is considered to be slight. Limestone that meets the specifications for some commercial uses crops out in the southeastern part of the area, but its inaccessibility, as compared with other limestone deposits in the region, lessens its potential commercial value. Rock units that contain commercial or potentially commercial deposits of diatomite, gypsum, and phosphate in nearby areas are not present in the primitive area. 


\section{INTRODUCTION}

\section{PURPOSE AND SCOPE}

The Wilderness Act of 1964 (Public Law 88-577, 88th Cong.) and related Conference Report (S. 4) direct the U.S. Geological Survey and the U.S. Bureau of Mines to make mineral surveys of primitive areas before these areas are considered by the President and Congress for inclusion in the National Wilderness Preservation System. To meet the provisions of these directives, the San Rafael primitive area, California, was examined in 1965 and is the subject of this report. The area described corresponds to the area under consideration for wilderness status; it is not identical with the San Rafael Primitive Area as originally defined because the proposed wilderness includes certain additional lands and excludes one small part of the original primitive area. The area as redefined is referred to in this report as the San Rafael primitive area.

This report is based only on the investigations of the U.S. Geological Survey. The U.S. Bureau of Mines did not have occasion to make field studies in the area because no mineral deposits approaching commercial grade were known there. The Bureau of Mines has been informed of the findings of the Geological Survey and concurs with the conclusions stated in this report.

No detailed geologic studies of the San Rafael primitive area had been made before the present investigations, although scanty reconnaissance data and knowledge of nearby areas indicated that petroleum, phosphate rock, limestone, and mercury might exist within the area. A reconnaissance geologic map, shown in simplified form on plate 1 , was made as a basis for evaluating the potential for petroleum, phosphate rock, and limestone. In addition, rocks that might contain phosphate were examined in detail in many places, and limestone outcroppings were sampled and analyzed for content of $\mathrm{CaCO}_{3}$ and deleterious impurities. Many samples of stream sediments and bedrock were analyzed for their mercury content; in addition, the stream sediments were analyzed for copper and other base metals (pl. 2).

\section{LOCATION AND ACCESSIBILITY}

The San Rafael primitive area is in Los Padres National Forest in the San Rafael and Sierra Madre Mountains in the southern part of the Coast Ranges of California (fig. 1). The area includes about 220 square miles, roughly forming a rectangle about 10-12 miles wide and 22 miles long, extending in a northwesterly direction (fig. 2). The area is about 13 miles north of Santa Barbara 


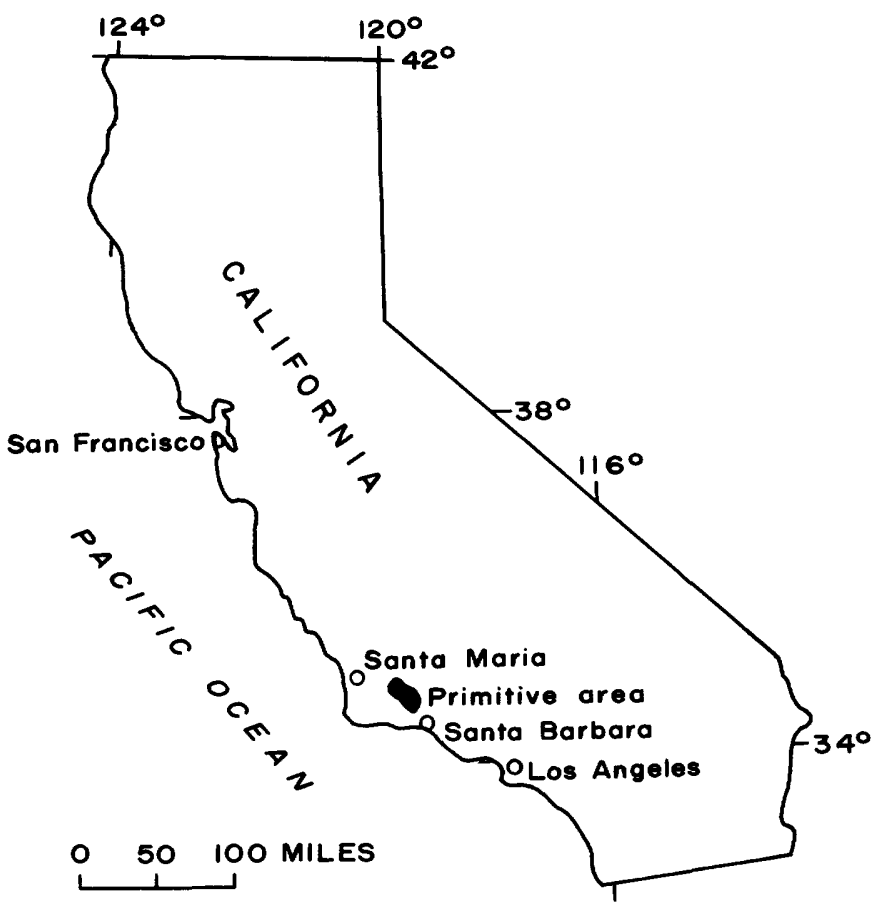

FIGURE 1.-Index map showing location of San Rafael primitive area.

and 25 miles southeast of Santa Maria; it is entirely within Santa Barbara County. The southern border can be reached by a gravelsurfaced public road to Manzana Creek and by a trail along Santa Cruz Creek. The Big Pine Road, a U.S. Forest Service fire road of limited access, closely follows the eastern boundary. The rest of the area can be reached only by trails south from the Sierra Madre Ridge Road near the northern boundary and along the valley of the Sisquoc River.

\section{TOPOGRAPHY AND VEGETATION}

The mountainous and rugged San Rafael area is characterized by steep-walled canyons and sharp ridges. Layers of resistant rock cropping out along the ridges and canyon walls form cliffs from 100 to more than 400 feet high (fig. 3).

Most of the slopes and ridges are densely covered by brush that is nearly impenetrable (fig. 4). Some slopes not covered by brush are mantled with yucca in such dense growths that travel by foot is often painfully difficult. Poison oak and scrub oak choke most of the drainages, but some of the larger stream valleys are relatively open. 


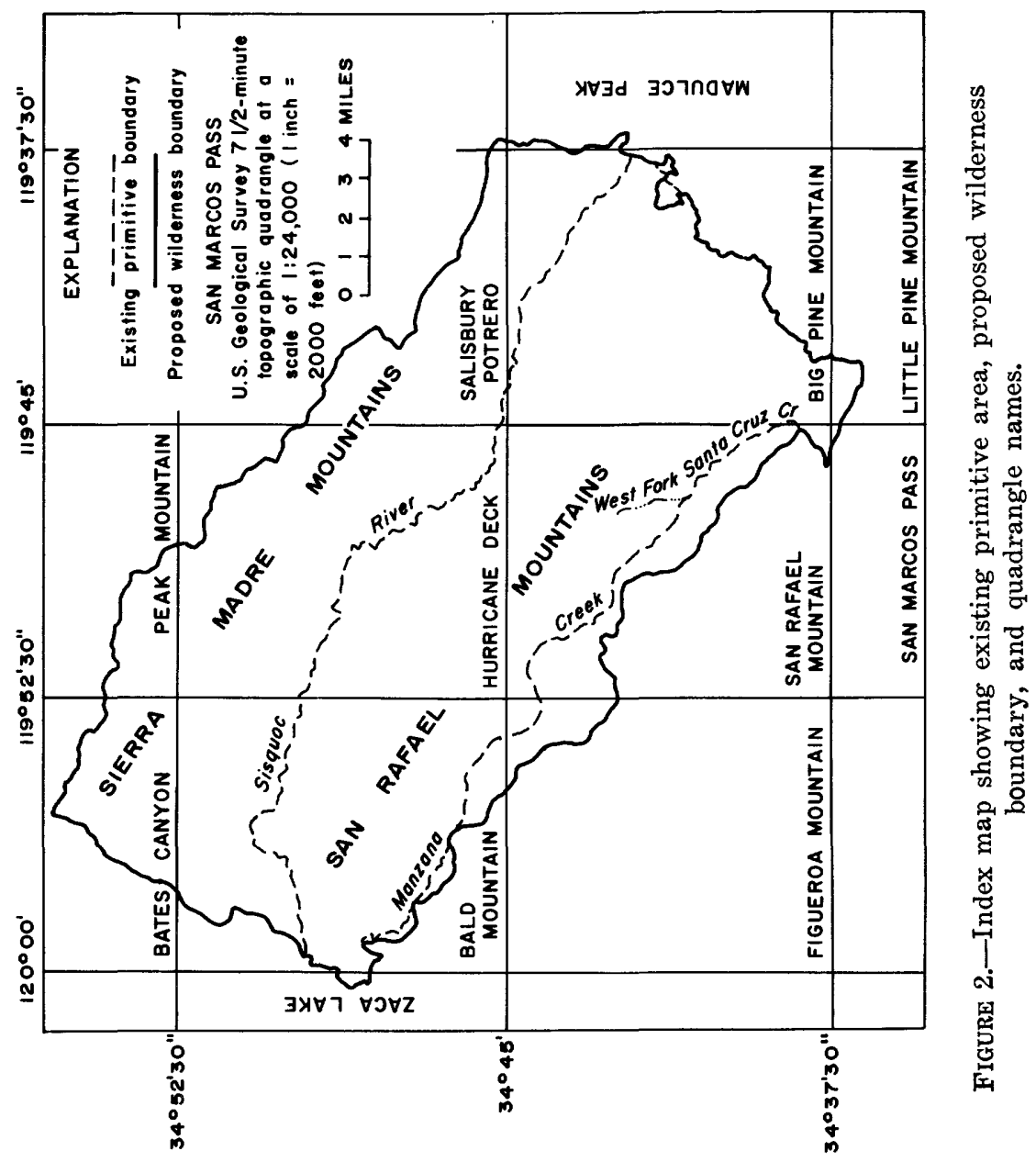


MINERAL RESOURCES, SAN RAFAEL PRIMITIVE AREA, CALIF. A5

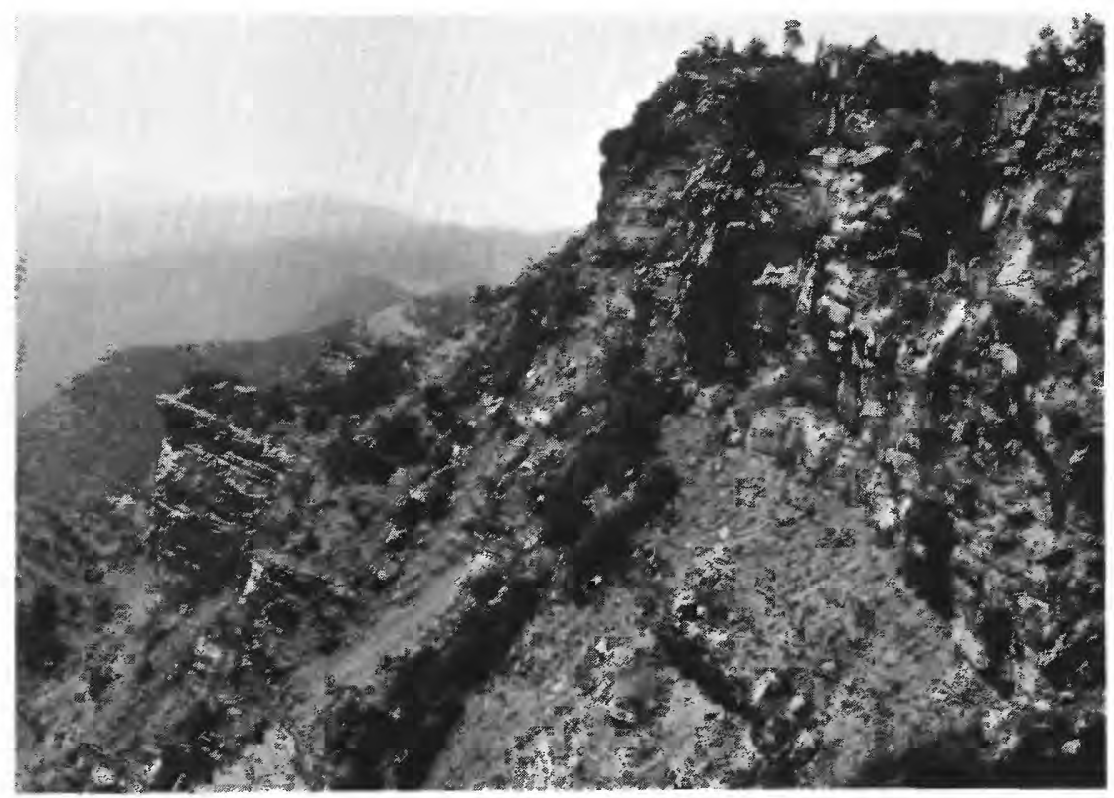

FIgURE 3.-Upper Cretaceous sandstone cliffs west of Big Pine Mountain. Lookout Tower at top of photograph. View looking west.

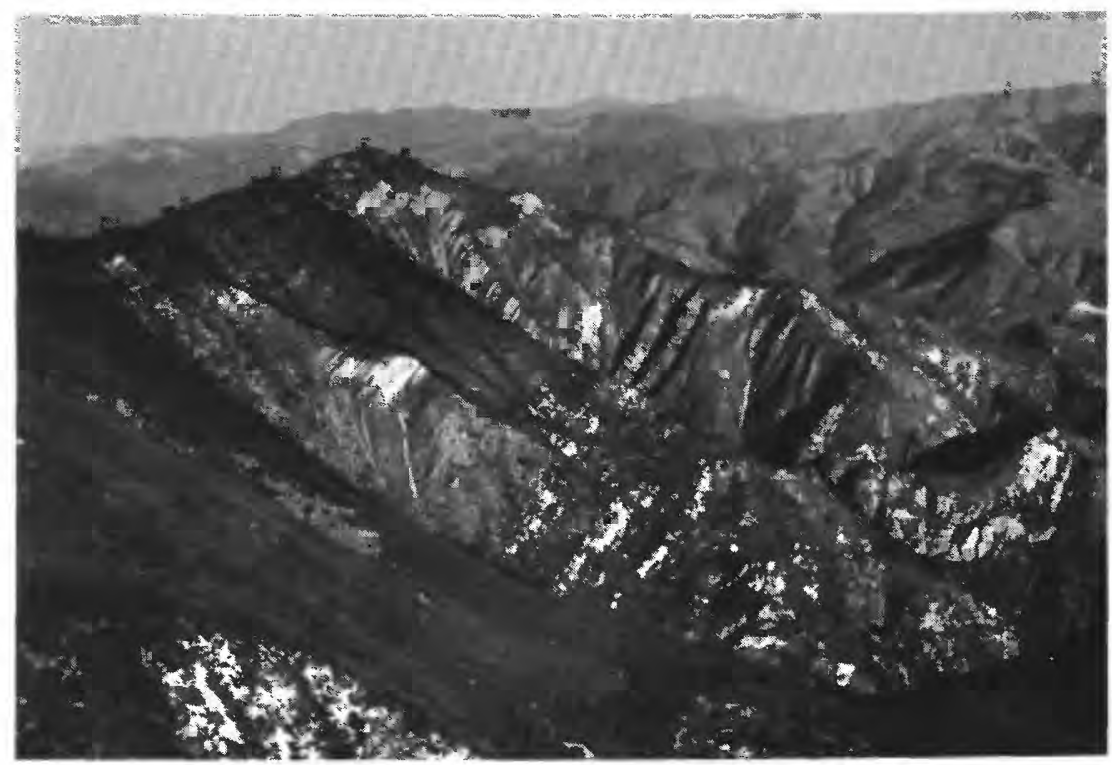

Figure 4.-Brush-covered shale and sandstone slopes on north side of Hurricane Deck. View looking west. 


\section{PREVIOUS WORK}

Before the present study, the geology of the San Rafael primitive area was not well known. Fairbanks (1894) described the general structure and stratigraphy along the line of a traverse across the central part of the area, apparently by way of the Jackson Trail to the Sisquoc River and then across the east end of Hurricane Deck to Manzana Creek. A small area near the junction of Manzana Creek and the Sisquoc River is included in the geologic map of the Santa Maria area by Arnold and Anderson (1907). Everhart (1950) included a small part of the primitive area in his description of the quicksilver deposits of the Cachuma mining district. Other geologic observations have been confined principally to the vicinity of the Big Pine Road, which closely follows the east boundary of the area. The siliceous shales of Miocene age in a small area south of the Hildreth fault were briefly described by Kew (1919). A generalized geologic map that includes part of the San Rafael primitive area south of the Big Pine fault was prepared by Nelson (1925). The Sierra Blanca Limestone of Nelson (1925) and two fossil localities in the vicinity of the East Fork of Santa Cruz Creek were described by Keenan (1932), and the limestone and its economic potential were later discussed by Walker (1950). A few geologic relationships along the Big Pine Road near the east boundary of the area were described by Reed and Hollister (1936). Some of the gross geologic features of the primitive area are shown on the Los Angeles sheet (preliminary edition) of the Geologic map of California (Kundert, 1955).

\section{FIELDWORK AND METHODS OF STUDY}

The initial studies of the San Rafael primitive area and bordering areas were made principally in April, May, and July 1965 by H. D. Gower, J. G. Vedder, H. E. Clifton, D. L. Durham, and E. E. Brabb. They were joined for a few days by T. W. Dibblee, Jr., who revised some of his earlier mapping in the area south of the Big Pine fault. E. V. Post and W. L. Lehmbeck spent 3 days in the field doing supplementary sampling and making geochemical analyses of bedrock and stream sediments. Cretaceous fossils were identified by D. L. Jones, Eocene and Miocene megafossils, by J. G. Vedder, and foraminifers, by P. B. Smith.

Following the public hearing on the proposed San Rafael Wilderness on November 8,1965 , the area proposed for inclusion was extended to the north and to the southwest. These additional areas were examined and mapped by Gower, Vedder, and Clifton in December 1965.

The field investigations were facilitated by use of a helicopter, which not only transported geologists to and from their traverses, 
MINERAL RESOURCES, SAN RAFAEL PRIMITIVE AREA, CALIF. A7

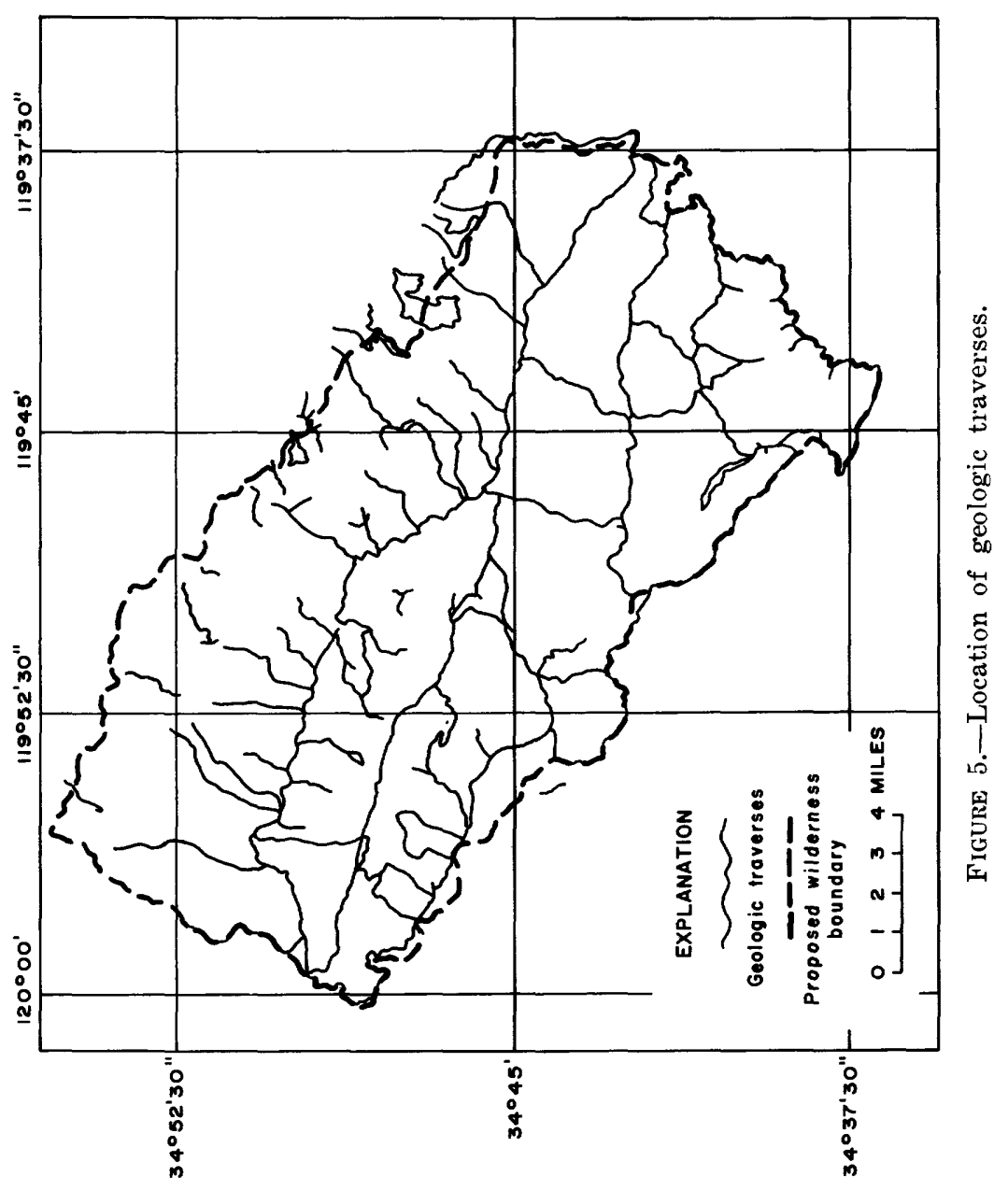


but which also was used to trace some of the rock units and structures. Use of the helicopter allowed complete coverage of the area in about 15 man-weeks.

The geologic map was prepared from traverse observations, helicopter overflights, and aerial photographs. The locations of the traverses are shown on figure 5. Visibility on the ground is limited in most places by brush or steep relief, and many contacts and faults were extended between traverses by careful study of aerial photographs. Nearly all the photogeologic interpretation was made by J. G. Vedder.

\section{GENERAL GEOLOGY}

The San Rafael primitive area is underlain by a thick sequence of Cretaceous and Tertiary sedimentary rocks. These rocks are mainly sandstone, conglomerate, siltstone, and shale, but they include some siliceous shale and minor amounts of limestone. Most of the rocks are of marine origin, but some continental deposits were also noted. The only igneous rocks in the area are a short dike and a small sill. The sedimentary strata are moderately folded and are cut by numerous faults, some of which extend many miles beyond the limits of the primitive area. Most of the major folds and faults trend northwest to west.

\section{STRATIGRAPHY}

The Cretaceous and Tertiary sedimentary rocks exposed in the San Rafael primitive area are about 22,000 feet thick. For purposes of this report the exposed rocks are divided on the basis of lithology and age into four units. Formational names are not applied to most of the rocks because the area occupies a central position with respect to three areas which have individual stratigraphic nomenclature: the Cuyama Valley area on the north, the Santa Barbara area on the south, and the Santa Maria area on the west. Additional field and paleontologic studies would be needed to select the nomenclature best suited for the rock units within the primitive area.

\section{CRETACEOUS ROCKS}

Conglomerate, sandstone, siltstone, and shale of Cretaceous age are the oldest and most widespread rocks in the primitive area. More than 7,000 feet of these rocks is exposed south of Hurricane Deck, but the total thickness is unknown. Fossils from 20 exposures of these rocks within the map area indicate a Late Cretaceous age.

The oldest of the Cretaceous rocks exposed in the area is conglomerate which crops out in a southeast-trending belt parallel to 
Manzana Creek. More than 1,000 feet of this conglomerate is exposed along Fish Creek. The conglomerate contains well-rounded pebbles, cobbles, and boulders of granitic and metavolcanic rocks in a matrix of clayey sandstone. It is thick bedded to massive, and contains thin lenses of greenish-gray clayey fine- to coarsegrained sandstone, most of which shows graded bedding. Southwest of the primitive area the conglomerate overlies the Jurassic to Early Cretaceous Espada Formation of Dibblee (1950), a thick sequence of thin-bedded shale with interbeds of fine-grained sandstone.

The conglomerate is overlain by sandstone and siltstone which together cover nearly half the primitive area. The sandstone is thin to thick bedded and commonly contains lenses of conglomerate and siltstone. The sandstone is predominantly light greenish gray to brownish gray, fine to very coarse grained, and poorly sorted. It has an abundant matrix of clay and silt and is commonly micaceous, but in a few places contains thick lenses of moderately well sorted light-gray to grayish-white feldspathic sandstone. The siltstone interbedded and intertongued with the sandstone is olive gray to dark gray and clayey to sandy. Most of it is thin bedded, but in some places bedding is indistinct. The siltstone commonly contains beds of greenish- to brownish-gray fine- to mediumgrained sandstone 1-3 inches thick; in places, it contains thick beds of sandstone and thin lenses of conglomerate. Most of the sandstone beds are graded, and calcareous concretions are locally abundant within the siltstone.

Indistinctly bedded locally cross bedded and channeled reddishand greenish-gray conglomerate, sandstone, and mudstone crop out along the south side of the Nacimiento(?) fault west of Sweetwater Canyon. Clasts in the pebble-boulder conglomerate are predominantly granitic and metavolcanic rocks, but a few are serpentine; granitic boulders are particularly abundant. Although the conglomerate is interbedded and intertongued with marine sandstone and siltstone, the absence of fossils, the reddish color, crossbedding and channeling, and generally poor bedding all suggest a nonmarine origin.

\section{TERTIARY ROCKS}

\section{EOCENE ROCKS}

A thick sequence of marine sedimentary rocks of Eocene age overlies the Upper Cretaceous strata. The total thickness of this sequence was not determined, but north of the Nacimiento(?) fault it appears to be more than 11,000 feet. The sequence differs on the two sides of the Big Pine fault, suggesting that the fault 
was active during Eocene time, or that significant post-Eocene lateral offset has taken place. South of the fault the Eocene sequence is marked by a distinctive basal limestone unit 100-200 feet thick, named the Sierra Blanca Limestone by Nelson (1925) : this basal unit is overlain by at least 5,000 feet of sandstone and siltstone that also contain a few thin lenses of conglomerate. On the north side of the Big Pine fault the limestone is absent, and the Eocene strata there are sandstone and conglomerate and minor amounts of siltstone. Locally on the south side of the fault, the Eocene rocks rest with marked angular unconformity on the Cretaceous strata; elsewhere they appear to be conformable.

The Sierra Blanca Limestone of Nelson (1925) crops out in a rather small area in the southeastern part of the primitive area. It typically is a white to light-gray massive limestone composed largely of fragmentary calcareous algae, large orbitoid Foraminifera, and finely crystalline calcium carbonate. It is commonly brecciated and recemented; locally it contains scattered grains of glauconite. In some places the limestone is sandy to clayey. Southeast of the East Fork of Santa Cruz Creek the limestone overlies Cretaceous strata with a marked angular unconformity, but elsewhere in the area the unconformity is not evident. Fossils from the limestone suggest that it is of middle Eocene age (Keenan, 1932; Walker, 1950, p. 4). Its correlation with Eocene strata north of the Big Pine fault is uncertain.

The Eocene strata above the Sierra Blanca Limestone are predominantly sandstone, although siltstone is locally abundant. The sandstones are brownish gray, fine to very coarse grained, thin to very thick bedded; they are commonly silty or clayey and here and there contain thin beds of dark-gray to brownish-gray siltstone. The sandstone is locally glauconitic and in a few places contains thin lenses of pebble and cobble conglomerate. It is unfossiliferous, but microfossils from the interbedded siltstone indicate a middle Eocene age.

North of Big Pine fault the Eocene sequence consists of sandstone with lenses of pebble and cobble conglomerate. The conglomerate lenses seem to be more abundant, thicker, and coarser westward. The sandstone is gray to yellowish brown, fine to very coarse grained, and commonly clayey or silty; it is thin to very thick bedded and contains thin interbeds of clayey siltstone. Most beds show graded bedding. Poorly preserved mollusks suggest an age range from early( ?) to middle Eocene.

\section{MIOCENE ROCKS}

Sedimentary rocks of early to middle Miocene age unconformably overlie the strata of Late Cretaceous and Eocene age in many 


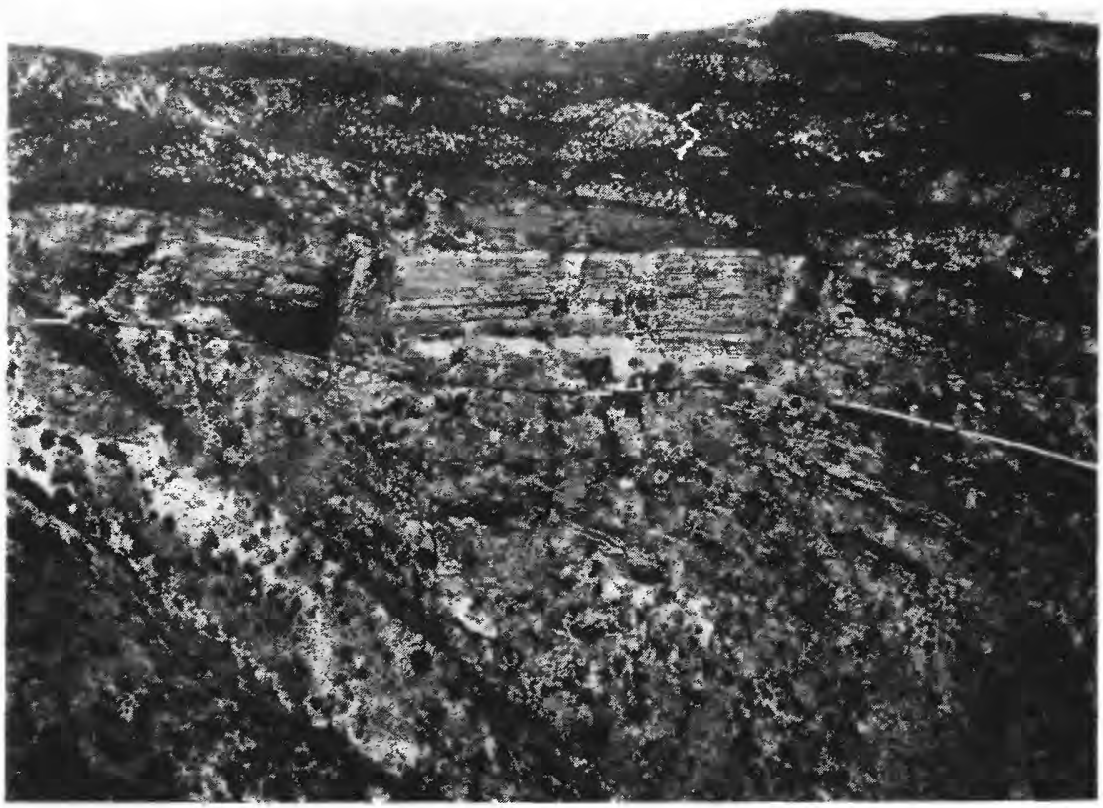

FigURE 6.-Unconformity between Miocene and Eocene rocks. View looking north from Sisquoc River.

parts of the primitive area (fig. 6). The Miocene rocks, consisting predominantly of sandstone, siltstone, claystone, and siliceous and calcareous shale, are thickest in the large syncline extending along Hurricane Deck, where about 4,000 feet of strata is exposed. In some places these rocks are interbedded in various combinations, but elsewhere a single variety or facies predominates over a wide area. The separate facies are not shown in detail on plate 1.

Locally on the south limb of the Hurricane Deck syncline and in a small syncline southeast of the Cachuma mining district, a reddish-to greenish-gray conglomerate as much as 200 feet thick forms the basal unit of the Miocene sequence and lies unconformably upon rocks of Late Cretaceous age. This conglomerate is poorly stratified and weakly consolidated and contains lenses of sandstone and mudstone. The pebbles, cobbles, and boulders were derived chiefly from the underlying sandstone and siltstone. The absence of fossils, the poor stratification, and red mudstone suggest a nonmarine origin.

A separate conglomerate unit, as much as 40 feet thick, lies at the base of the Miocene sequence in places in two small synclines along the southeast edge of the area. This conglomerate contains abundant clasts of white limestone probably derived from the 
Sierra Blanca Limestone of Nelson (1925); it also includes beds of glauconitic sandstone.

Sandstone of the Miocene sequence occupies an extensive area along Hurricane Deck, but similar sandstone also occurs in many smaller isolated areas. It is thin to very thick bedded, and although it includes thin beds of claystone and siltstone, it commonly forms resistant ledges, particularly on the southeast end of the Hurricane Deck syncline. The sandstone is brown to white, fine to coarse grained, feldspathic, and is locally glauconitic and crossbedded at the base. Graded bedding is also common throughout. The lower part of the sandstone intertongues with claystone in many parts of the area, and the upper part intertongues with siliceous and calcareous shale on Hurricane Deck.

Silty claystone and clayey siltstone containing thin beds of finegrained feldspathic sandstone are distinctive components of the Miocene sequence in several areas. The claystone and siltstone are bluish gray to brownish gray and thin to indistinctly bedded. They locally contain thin calcareous lenses and in a few places are tuffaceous.

Shale of Miocene age crops out along the axis of the Hurricane Deck syncline and south of the Hildreth fault. This unit is composed chiefly of light-brown to white shale and silty claystone, but it includes thin beds and lenses of light-gray fine-grained feldspathic sandstone and very thin beds of tuff and bentonite. It is commonly siliceous and calcareous and locally is highly diatomaceous. Foraminifers are locally very abundant, nearly covering the bedding surfaces in some places. Calcareous concretions occur locally, and cherty lenses are common in a very thin bedded zone in the upper part of the unit along Hurricane Deck.

\section{INTRUSIVE IGNEOUS ROCKS}

Two small intrusions of mafic igneous rock were found within the San Rafael primitive area. A diabase dike about 20 feet thick cuts Upper Cretaceous siltstone near the junction of Miller Canyon and the Sisquoc River. It is exposed for only a few hundred feet. A diabase sill, 30-50 feet thick and about a mile long, intrudes Miocene sandstone and shale on the West Fork of Santa Cruz Creek. The rocks in both occurrences are brownish gray and fine grained; they are tentatively assigned a Miocene or younger age.

\section{PLEISTOCENE AND RECENT DEPOSITS}

Erosional remnants of alluvium of probable Pleistocene age are present along many of the larger streams. These deposits consist of silt, sand, and gravel that are weakly indurated in some locali- 
ties. The deposits are most common along the Sisquoc River where they form prominent terraces at several levels.

Recent alluvial deposits of silt, sand, and gravel are present in channels and on flood plains of all the major streams in the primitive area.

Deposits of light-gray to brownish-gray travertine are present in several places along Sulphur Spring Canyon. The largest deposit, near the mouth of the canyon, forms a lenticular body 10-20 feet thick and 90 feet long. The other deposits are much smaller, consisting of coatings less than 1 foot thick on bedrock surfaces.

\section{STRUCTURE}

The rocks in the primitive area are moderately to intensely faulted and folded. Deformation occurred after each episode of sedimentation recorded by the Cretaceous, Eocene, and Miocene rocks. As a result, the older rocks generally are more steeply dipping and faulted than the younger ones, and unconformities separate the main sedimentary sequences. Most major folds and faults trend N. $60^{\circ}-80^{\circ} \mathrm{W}$., following the general alinement of the southern Coast Range structures. From north to south the principal structural features of the primitive area are the Madulce syncline, Nacimiento(?) fault, Hurricane Deck syncline, Mission Pine anticline, Big Pine fault, and Hildreth fault.

\section{FOLDS}

Three main folds, the Madulce and Hurricane Deck synclines on the north and the Mission Pine anticline on the south, dominate the fold pattern in the area. Many smaller folds parallel these major structures, particularly in the area between the Nacimiento(?) fault and the Hurricane Deck syncline. Strata within the major flexures range in attitude from flat lying to nearly vertical, but most commonly dip $30^{\circ}-50^{\circ}$.

The Madulce syncline is the principal fold north of the Nacimiento(?) fault, and the Hurricane Deck syncline and Mission Pine anticline are the principal folds south of the fault. The Madulce syncline trends about N. $60^{\circ}$ W., parallel to the Nacimiento(?) fault. The fold axis seems to be offset in an en echelon pattern by a set of northeast-trending cross faults. The axis is well defined east of Mine Canyon, but to the west its location is uncertain, although a large fold continues northwest from Oak Canyon to Water Canyon and beyond. The large Hurricane Deck syncline extends from the west boundary of the primitive area eastward for nearly 19 miles where it terminates against the Nacimiento(?) 
fault near the junction of Judell Canyon and the Sisquoc River. This syncline is asymmetric, having the steeper limb on the north. Several west-trending small folds and faults flank the syncline on the north. The Mission Pine anticline, a broad east-plunging structure south of the Hurricane Deck syncline, terminates against the Big Pine fault on the east and against a branch of the Big Pine fault near McKinley Mountain, just outside the western boundary of the primitive area. The crest of the anticline is offiset in several places by north-trending cross faults. A moderate-sized syncline lies at the southern border of the area, south of the Hildreth fault, but only a short segment of the axis of this fold lies within the primitive area.

\section{FAULTS}

Some of the larger faults in the San Rafael primitive area are among the major structural elements of the Coast Range fault system, and extend far beyond the borders of the primitive area. The two principal faults, the Nacimiento(?) and Big Pine faults, extend more than 100 miles north and 40 miles east of the primitive area, respectively. Both of these structures are probably

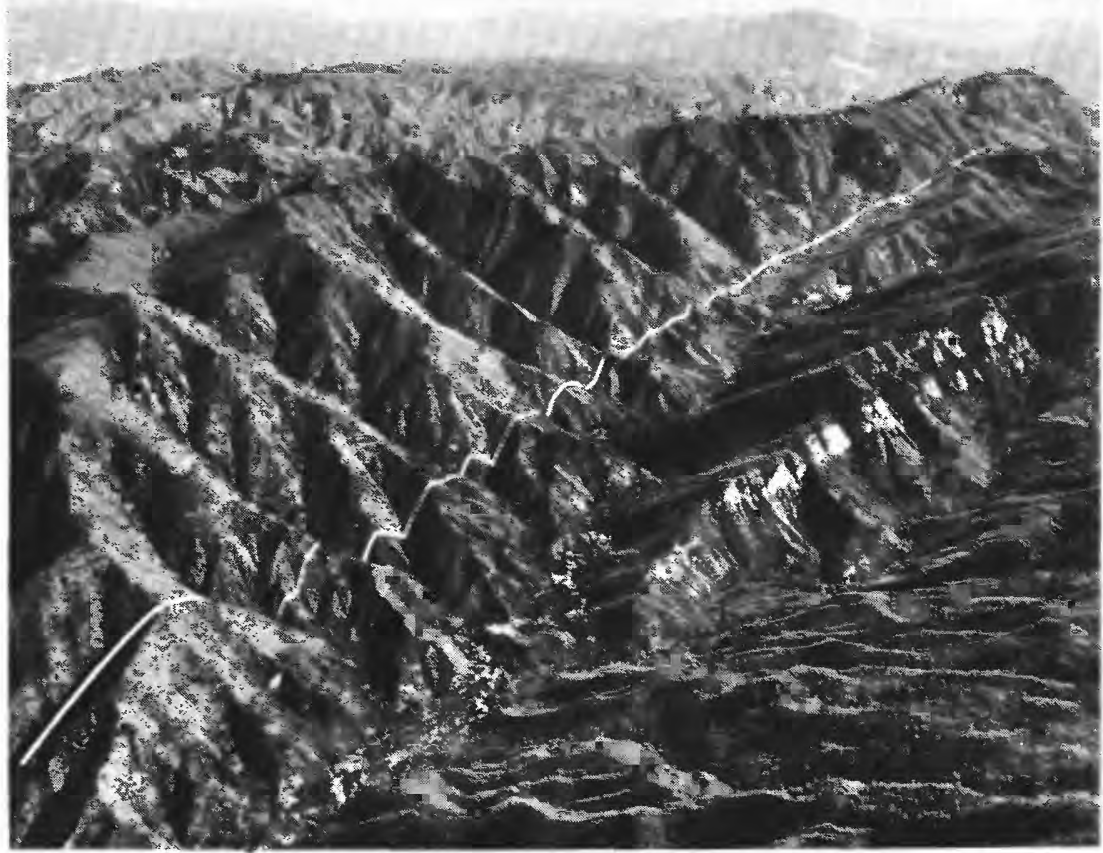

Frgure 7.-Canyon of Sisquoc River and trace of Nacimiento(?) fault. View looking east. 
strike-slip faults; the other, smaller faults have apparent displacements that are nearly vertical.

The Nacimiento(?) fault is the most prominent structural feature in the area (fig. 7). Lying north of the Sisquoc River it crosses the entire length of the primitive area, separating Eocene from Cretaceous rocks over most of its trace. It strikes about $\mathrm{N}$. $60^{\circ} \mathrm{W}$. and dips $70^{\circ}-80^{\circ} \mathrm{N}$., although the fault plane seems to be folded slightly in places. The fault name is queried in this report because of the uncertain identity of the Nacimiento fault in this region, although the fault in this area trends into the Nacimiento fault as shown on the San Luis Obispo sheet of the Geologic map of California (Jennings, 1959). Other geologists, including Hill and Dibblee (1953), Crowell (1962), and others, apply the name to a major fault lying several miles north of the primitive area.

The amount and direction of displacement along the Nacimiento(?) fault are not fully known. The juxtaposition of Eocene rocks on the north against Cretaceous rocks on the south along most of the trace of this fault in the primitive area suggests relative downdropping of the north side, but in the vicinity of Sweetwater Canyon the relation of Miocene rocks on the south to Eocene rocks on the north suggests movement in the opposite direction. These relations indicate either a reversal in the direction of movement between pre- and post-Miocene time, or, more likely, that movement has been chiefly lateral. The Nacimiento(?) fault seems to merge with the Big Pine fault about 3 miles east of the primitive area.

The Big Pine fault trends about N. $80^{\circ}$ W., east of Grapevine Creek. At Grapevine Creek it bifurcates. One branch extends due west for several miles before swinging northwest outside the primitive area; the other, the main branch, bends to the southwest and extends in that direction to the edge of the area. The Big Pine fault apparently dips $60^{\circ}-70^{\circ} \mathrm{N}$., and is relatively upthrown on the north; but east of Cache Creek several drainages appear to be offset as much as 3,000 feet in a left-lateral direction along this fault. East of the primitive area the Big Pine fault is postulated to have as much as $\mathbf{1 0}$ miles of left-lateral displacement (Crowell, 1962, p. 34).

The Hildreth fault, which lies near the southern boundary of the primitive area, trends about N. $65^{\circ} \mathrm{W}$. Only a small segment of this fault lies within the primitive area. The fault appears to be nearly vertical. The nature of the displacement is uncertain, but the north side of the fault appears to be upthrown. West of the 
primitive area the Hildreth fault passes beneath the north-dipping Big Pine fault.

Numerous smaller faults also exist in the primitive area. Most of these trend north to northeast, transverse to the trend of major structural features. The fault planes dip steeply, and movement of most was normal.

\section{MINERAL RESOURCES}

\section{SETTING}

The southern Coast Ranges of California contain important deposits of petroleum, mercury, diatomite, and other mineral commodities. These commodities, however, are localized in specific geologic environments of limited extent, and their occurrence is dependent on certain geologic factors. In general, the San Rafael primitive area lacks the geologic factors associated with the occurrence of major mineral deposits, despite the fact that important deposits are present nearby.

The primitive area is flanked, at distances of several miles, on the north, west, and south by producing oil fields, and on the southwest it is bordered by the once-productive Cachuma quicksilver district. Geologic conditions indicate, however, that the occurrence of either of these commodities in commercial quantities within the primitive area is unlikely. Although marine rocks of Miocene age, which have been prolific producers of petroleum in nearby oil fields, underlie about 25 percent of the primitive area, they lack potential trap structures except on a relatively small scale. The rest of the primitive area is occupied by rocks of Late Cretaceous and Eocene age, which have produced little or no petroleum in nearby areas. The quicksilver deposits of the southern Coast Ranges typically occur with carbonate-altered rock in the Franciscan Formation (Jurassic and Cretaceous) and closely associated serpentine intrusions. These rock types are not known in the San Rafael primitive area. The Sierra Blanca Limestone of Nelson (1925), a possible source of cement rock and lime products, occurs in several places in the southern Coast Ranges. It is present in the primitive area, but it may not be of commercial interest because of steep terrain and the relative remoteness of the limestone deposits from railroads and highways. Rocks of late Miocene and Pliocene age contain large commercial deposits of diatomite near Lompoc, 15-25 miles southwest of the primitive area, and several small deposits of gypsum a few miles northeast of the primitive area; however, the rocks containing these deposits do not extend into the primitive area. Potentially commercial deposits of phosphate are present in middle to upper Miocene siliceous 
shales in several places in the southern Coast Ranges, but they are not present in the primitive area.

The U.S. Bureau of Mines found only five mineral claims, or groups of claims, that seem to have been located within the San Rafael primitive area. None of the discovery pits on these claims were recognized in the field, although one prospect not previously recorded was found along the Sisquoc River about 3,000 feet northwest of the mouth of Foresters Leap Canyon. This prospect consists of an adit 15 feet long driven in Upper Cretaceous sandstone; no evidence of mineralization was seen. There is no record of any mineral production from within the primitive area.

All the original primitive area and nearly all the area added south of the original boundary was withdrawn from all oil and gas lease applications on January 27, 1953, by the U.S. Department of the Interior under Public Land Order 2714.

Nearly all the primitive area south of T. $8 \mathrm{~N}$. and east of San Rafael Mountain was withdrawn, with other lands, by the act of April 20, 1936 (H.R. Bill 6544, Public Law 526, 74th Cong.), from location or entry under the United States mining laws, in order to conserve the water resources and to encourage reforestation of the watersheds of Santa Barbara County.

\section{MERCURY}

Many quicksilver (mercury) deposits, including the nation's largest producers, occur in the Coast Ranges of California. The Cachuma district, one of the southernmost of California's quicksilver-producing districts, adjoins the southwest boundary of the San Rafael primitive area. This mining district, inactive in recent years, began production in 1867 (Everhart, 1950, p. 512-515), but the rather small total output of 3,340 flasks does not place the district among the leaders in California's mercury industry. Everhart's study (1950) revealed little possibility for the discovery of significant amounts of additional ore in the district.

Because of the proximity of this once-productive quicksilver mining district to the San Rafael primitive area, a careful but fruitless search was made for visual evidence of similar deposits within the primitive area. The quicksilver ore of the Cachuma district occurs in thin-bedded siltstone, shale, and sandstone of late Jurassic or early Cretaceous age, the Espada Formation of Dibblee (1950), which have been intruded by several small sill-like bodies of serpentine. The ore is closely associated with carbonate rock and clay formed before mineralization by the alteration of rocks and filling of voids along faults (Everhart, 1950). The carbonate rock, being more resistant to erosion than unaltered rock, 
crops out as prominent light-colored "reefs," readily noticed from the ground or from the air. No carbonate rock, serpentine, or rock as old as the Espada Formation was noted in the primitive area.

In the absence of visible indications of quicksilver deposits in the area, a geochemical exploration program was undertaken to search for evidence of unexposed deposits. The locations of geochemical samples are shown on plate 2 , and the mercury values are given in table 1. Greatest emphasis was placed on that part of the primitive area nearest the known deposits of the Cachuma district. Some work was done initially in this district to determine the amount of mercury that might be dispersed in apparently barren rocks near ore bodies. These initial studies indicated that values greater than $500 \mathrm{ppb}$ (parts per billion) mercury in stream sediment or $1,000 \mathrm{ppb}$ or more mercury in rock should be considered anomalous.

Standard geochemical prospecting techniques were employed. Both stream sediments and rocks were sampled. Stream-sediment sampling is a widely accepted technique of appraising the mineral potential of large areas, inasmuch as abnormal amounts of metal commonly are found in stream sediments for a considerable distance downstream from concealed mineral deposits. Rocks were also sampled to detect the possible occurrence of anomalously high amounts of mercury that commonly surround known quicksilver deposits. All samples were analyzed for mercury by an atomicabsorption method (Vaughn and McCarthy, 1964).

The initial results of the geochemical prospecting investigation focused attention on the Manzana Creek drainage, where values for mercury in stream sediments were generally higher than in the rest of the primitive area (pl. 2). Anomalous concentrations of mercury were also noted in sandstone in Sulphur Spring Canyon, $21 / 2-3$ miles northeast of the Cachuma district, where samples of sandstone were found to contain as much as $3,300 \mathrm{ppb}$ mercury-about 80 times higher than the median value in the primitive area, but still only about one-thousandth of ore grade. Samples of shale from Sulphur Spring Canyon contain only average amounts of mercury, in contrast to shale in the Cachuma district, whose mercury content of $1,000 \mathrm{ppb}$ is 25 times the average. Mercury vapor is able to migrate far more readily through sandstone than through shale, because of the greater permeability of the sandstone. This probably accounts for the fact that the highest values for mercury obtained in rock samples are in sandstone.

Although mercury concentrations of as much as 3,300 ppb are large compared to the median value of $40 \mathrm{ppb}$ for rocks in this area, they are low in relation to values obtained from rocks over- 
MINERAL RESOURCES, SAN RAFAEL PRIMITIVE AREA, CALIF. A19

Table 1.--Geochemical analyses.

[Mercury (Hg) in parts per billion, citrate-soluble heavy metals (cxHM) and cold acid-extractable copper (cxCU) in parts per million. Analysts:

W. L. Lehmbeck, H. McCarthy, and W. P. McKay]

\begin{tabular}{|c|c|c|c|c|c|c|c|c|c|}
\hline $\begin{array}{l}\text { Samp le } \\
\text { No. }\end{array}$ & $\mathrm{Hg}$ & cxHM & $\mathrm{cxCU}$ & Sample description & $\begin{array}{l}\text { Sample } \\
\text { No. }\end{array}$ & $\mathrm{Hg}$ & cXHM & $\mathrm{cxCU}$ & Sample description \\
\hline $\begin{array}{l}1 \\
2 \\
3 \\
4 \\
5\end{array}$ & $\begin{array}{r}<10 \\
10 \\
<10 \\
10 \\
20\end{array}$ & & & $\begin{array}{l}\text { Sandstone } \\
\text { Siltstone } \\
\text { Siltstone } \\
\text { Sandstone } \\
\text { Shale }\end{array}$ & $\begin{array}{l}148 \\
149 \\
150 \\
151 \\
152\end{array}$ & $\begin{array}{r}28 \\
24 \\
28 \\
320 \\
80\end{array}$ & $\begin{array}{r}3 \\
3 \\
45 \\
11 \\
7\end{array}$ & $\begin{array}{c}6 \\
6 \\
11 \\
<0.5 \\
3\end{array}$ & $\begin{array}{l}\text { Siltstone } \\
\text { Siltstone } \\
\text { Shale } \\
\text { Shale } \\
\text { Shale }\end{array}$ \\
\hline $\begin{array}{l}6 \\
7 \\
8 \\
9 \\
10\end{array}$ & $\begin{array}{r}1,400 \\
40 \\
200 \\
140 \\
20\end{array}$ & & & $\begin{array}{l}\text { Sandstone } \\
\text { Siltstone } \\
\text { Siltstone } \\
\text { Sandstone } \\
\text { Shale }\end{array}$ & $\begin{array}{l}153 \\
154 \\
156 \\
157 \\
158\end{array}$ & $\begin{array}{r}220 \\
136 \\
24 \\
28 \\
104\end{array}$ & $\begin{array}{l}9 \\
3 \\
2 \\
5 \\
2\end{array}$ & $\begin{array}{l}4 \\
1 \\
4 \\
1.5 \\
4\end{array}$ & $\begin{array}{l}\text { Siltstone } \\
\text { Siltstone } \\
\text { Siltstone(?) } \\
\text { Shale } \\
\text { Siltstone }\end{array}$ \\
\hline $\begin{array}{l}11 \\
12 \\
13 \\
14 \\
15\end{array}$ & $\begin{array}{r}<10 \\
20 \\
<10 \\
40 \\
100\end{array}$ & & & $\begin{array}{l}\text { Sandstone } \\
\text { Shale } \\
\text { Sandstone } \\
\text { Sandstone } \\
\text { Siltstone }\end{array}$ & $\begin{array}{l}170 \\
171 \\
172 \\
173 \\
174\end{array}$ & $\begin{array}{r}40 \\
700 \\
20 \\
60 \\
180\end{array}$ & & & $\begin{array}{l}\text { Siltstone } \\
\text { Shale } \\
\text { Sand stone } \\
\text { Siltstone } \\
\text { Sandstone }\end{array}$ \\
\hline $\begin{array}{l}16 \\
17 \\
18 \\
19 \\
20\end{array}$ & $\begin{array}{l}20 \\
30 \\
20 \\
20 \\
40\end{array}$ & & & $\begin{array}{l}\text { Siltstone } \\
\text { Sandstone } \\
\text { Sandstone } \\
\text { Sandstone } \\
\text { Siltstone }\end{array}$ & $\begin{array}{l}175 \\
176 \\
177 \\
178 \\
159\end{array}$ & $\begin{array}{r}70 \\
50 \\
140 \\
40 \\
550\end{array}$ & & & $\begin{array}{l}\text { Siltstone } \\
\text { Shale } \\
\text { Sandstone } \\
\text { Siltstone } \\
\text { Sandstone }\end{array}$ \\
\hline $\begin{array}{l}21 \\
26 \\
35 \\
36 \\
37\end{array}$ & $\begin{array}{r}3,300 \\
40 \\
40 \\
10 \\
900\end{array}$ & & & $\begin{array}{l}\text { Sand stone } \\
\text { Tufa } \\
\text { Shale } \\
\text { Tufa } \\
\text { Sand stone }\end{array}$ & $\begin{array}{l}180 \\
181 \\
182 \\
183 \\
184\end{array}$ & $\begin{array}{r}30 \\
10 \\
20 \\
450 \\
70\end{array}$ & & & $\begin{array}{l}\text { Siltstone } \\
\text { Shale } \\
\text { Sandstone } \\
\text { Sandstone } \\
\text { Siltstone }\end{array}$ \\
\hline $\begin{array}{l}101 \\
102 \\
103 \\
104 \\
105\end{array}$ & $\begin{array}{l}40 \\
16 \\
72 \\
76 \\
24\end{array}$ & $\begin{array}{l}0.5 \\
0.5 \\
2 \\
1 \\
<0.5\end{array}$ & $\begin{array}{l}2 \\
2 \\
4 \\
3 \\
1.5\end{array}$ & $\begin{array}{l}\text { Alluvium } \\
\text { Alluvium } \\
\text { Alluvium } \\
\text { Alluvium } \\
\text { Alluvium }\end{array}$ & $\begin{array}{l}185 \\
186 \\
187 \\
190 \\
192\end{array}$ & $\begin{array}{r}40 \\
30 \\
20 \\
1,100 \\
<10\end{array}$ & & & $\begin{array}{l}\text { Sandstone } \\
\text { Siltstone } \\
\text { Shale } \\
\text { Sandstone } \\
\text { Shale }\end{array}$ \\
\hline $\begin{array}{l}106 \\
107 \\
108 \\
109 \\
110\end{array}$ & $\begin{array}{l}48 \\
32 \\
16 \\
12 \\
16\end{array}$ & $\begin{array}{l}2 \\
2 \\
2 \\
1 \\
0.5\end{array}$ & $\begin{array}{l}3 \\
1.5 \\
1.5 \\
3 \\
2\end{array}$ & $\begin{array}{l}\text { Alluvium } \\
\text { Alluvium } \\
\text { Alluvium } \\
\text { Alluvium } \\
\text { Alluvium }\end{array}$ & $\begin{array}{l}193 \\
194 \\
195 \\
200 \\
201\end{array}$ & $\begin{array}{r}100 \\
20 \\
20 \\
64 \\
20\end{array}$ & $\begin{array}{r}0.5 \\
<0.5\end{array}$ & $\begin{array}{l}1 \\
1.5\end{array}$ & $\begin{array}{l}\text { Sandstone } \\
\text { Shale } \\
\text { Siltstone } \\
\text { Alluvium } \\
\text { Alluvium }\end{array}$ \\
\hline $\begin{array}{l}112 \\
113 \\
115 \\
116 \\
117\end{array}$ & $\begin{array}{l}32 \\
24 \\
26 \\
16 \\
24\end{array}$ & $\begin{array}{c}1 \\
0.5 \\
0.5 \\
11 \\
2\end{array}$ & $\begin{array}{l}2 \\
1.5 \\
1.5 \\
6 \\
3\end{array}$ & $\begin{array}{l}\text { Alluvium } \\
\text { Alluvium } \\
\text { Breccia } \\
\text { Shale } \\
\text { Sand stone }\end{array}$ & $\begin{array}{l}202 \\
203 \\
204 \\
301 \\
302\end{array}$ & $\begin{array}{r}10 \\
156 \\
60 \\
36 \\
88\end{array}$ & $\begin{array}{r}<0.5 \\
0.5 \\
0.5 \\
0.5 \\
0.5\end{array}$ & $\begin{array}{l}1.5 \\
3 \\
1.5 \\
3 \\
1.5\end{array}$ & $\begin{array}{l}\text { Alluvium } \\
\text { Alluvium } \\
\text { Alluvium } \\
\text { Alluvium } \\
\text { Alluvium }\end{array}$ \\
\hline $\begin{array}{l}118 \\
119 \\
120 \\
121 \\
123\end{array}$ & $\begin{array}{r}20 \\
1,400 \\
120 \\
580 \\
92\end{array}$ & $\begin{array}{l}3 \\
5 \\
<0.5 \\
2 \\
3\end{array}$ & $\begin{array}{l}8 \\
1.5 \\
1 \\
<0.5 \\
4\end{array}$ & $\begin{array}{l}\text { Shale } \\
\text { Sand stone } \\
\text { Sand stone } \\
\text { Sand stone } \\
\text { Shale }\end{array}$ & $\begin{array}{l}303 \\
304 \\
305 \\
306 \\
307\end{array}$ & $\begin{array}{r}76 \\
72 \\
52 \\
44 \\
156\end{array}$ & $\begin{aligned} & 0.5 \\
& 0.5 \\
& 1 \\
&<0.5\end{aligned}$ & $\begin{array}{c}<0.5 \\
3 \\
3 \\
2\end{array}$ & $\begin{array}{l}\text { Alluvium } \\
\text { Alluvium } \\
\text { Alluvium } \\
\text { Alluvium } \\
\text { Alluvium }\end{array}$ \\
\hline $\begin{array}{l}124 \\
125 \\
126 \\
127 \\
128\end{array}$ & $\begin{array}{r}145 \\
760 \\
8 \\
52 \\
24\end{array}$ & $\begin{array}{l}2 \\
7 \\
0.5 \\
2 \\
2\end{array}$ & $\begin{aligned} & 1 \\
& 4 \\
& 2 \\
< & 0.5 \\
< & 0.5\end{aligned}$ & $\begin{array}{l}\text { Conglomerate } \\
\text { Shale } \\
\text { Sandstone } \\
\text { Shale } \\
\text { Shale }\end{array}$ & $\begin{array}{l}308 \\
309 \\
310 \\
311 \\
312\end{array}$ & $\begin{array}{l}28 \\
16 \\
24 \\
24 \\
44\end{array}$ & $\begin{array}{l}0.5 \\
0.5 \\
1 \\
0.5 \\
0.5\end{array}$ & $\begin{array}{c}1.5 \\
1 \\
<0.5 \\
3 \\
2\end{array}$ & $\begin{array}{l}\text { Alluvium } \\
\text { Alluvium } \\
\text { Alluvium } \\
\text { Alluvium } \\
\text { Alluvium }\end{array}$ \\
\hline $\begin{array}{l}129 \\
130 \\
132 \\
133 \\
136\end{array}$ & $\begin{array}{r}1,400 \\
24 \\
12 \\
24 \\
480\end{array}$ & $\begin{array}{l}2 \\
2 \\
0.5 \\
1 \\
0.5\end{array}$ & $\begin{array}{c}2 \\
6 \\
1 \\
1 \\
<0.5\end{array}$ & $\begin{array}{l}\text { Sand stone } \\
\text { Siltstone } \\
\text { Sand stone } \\
\text { Conglomerate } \\
\text { Conglomerate }\end{array}$ & $\begin{array}{l}313 \\
314 \\
315 \\
400 \\
401\end{array}$ & $\begin{array}{l}60 \\
10 \\
60 \\
96 \\
88\end{array}$ & $\begin{array}{l}0.5 \\
1 \\
1 \\
0.5 \\
2\end{array}$ & $\begin{array}{l}1.5 \\
2 \\
1.5 \\
3 \\
1.5\end{array}$ & $\begin{array}{l}\text { Alluvium } \\
\text { Alluvium } \\
\text { Alluvium } \\
\text { Alluvium } \\
\text { Alluvium }\end{array}$ \\
\hline $\begin{array}{l}137 \\
138 \\
139 \\
140 \\
141\end{array}$ & $\begin{array}{r}1,060 \\
96 \\
36 \\
92 \\
28\end{array}$ & $\begin{array}{l}7 \\
1 \\
2 \\
2 \\
2\end{array}$ & $\begin{array}{r}1 \\
3 \\
15 \\
1.5 \\
1.5\end{array}$ & $\begin{array}{l}\text { Sand stone } \\
\text { Shale } \\
\text { Shale } \\
\text { Sand stone } \\
\text { Conglomerate }\end{array}$ & $\begin{array}{l}402 \\
403 \\
404 \\
410 \\
411\end{array}$ & $\begin{array}{l}24 \\
10 \\
24 \\
12 \\
16\end{array}$ & $\begin{array}{r}<0.5 \\
0.5 \\
<0.5 \\
<0.5 \\
0.5\end{array}$ & $\begin{array}{l}1.5 \\
1 \\
1.5 \\
< \\
2.5\end{array}$ & $\begin{array}{l}\text { Alluvium } \\
\text { Alluvium } \\
\text { Alluvium } \\
\text { Alluvium } \\
\text { Alluvium }\end{array}$ \\
\hline $\begin{array}{l}142 \\
143 \\
144 \\
145 \\
147\end{array}$ & $\begin{array}{l}10 \\
44 \\
76 \\
12 \\
40\end{array}$ & $\begin{array}{l}2 \\
2 \\
7 \\
0.5 \\
5\end{array}$ & $\begin{array}{l}4 \\
4 \\
4 \\
2 \\
6\end{array}$ & $\begin{array}{l}\text { Siltstone } \\
\text { Shale } \\
\text { Siltstone } \\
\text { Siltstone } \\
\text { Siltstone }\end{array}$ & $\begin{array}{l}412 \\
414 \\
415 \\
416 \\
417\end{array}$ & $\begin{array}{r}196 \\
720 \\
60 \\
144 \\
152\end{array}$ & $\begin{array}{l}3 \\
1 \\
7 \\
2 \\
4\end{array}$ & $\begin{array}{l}4 \\
1.5 \\
8 \\
6 \\
4\end{array}$ & $\begin{array}{l}\text { Alluvium } \\
\text { Alluvium } \\
\text { Alluvium } \\
\text { Alluvium } \\
\text { Alluvium }\end{array}$ \\
\hline
\end{tabular}


Table 1,--Geochemical analyses--Continued

\begin{tabular}{|c|c|c|c|c|c|c|c|c|c|}
\hline $\begin{array}{l}\text { Sample } \\
\text { No. }\end{array}$ & $\mathrm{Hg}$ & $\operatorname{cxHM}$ & $\mathrm{cxCU}$ & Sample description & $\begin{array}{l}\text { Sample } \\
\text { No. }\end{array}$ & $\mathrm{Hg}$ & exHM & $\operatorname{cxcu}$ & Sample description \\
\hline $\begin{array}{l}419 \\
420 \\
421 \\
430 \\
431\end{array}$ & $\begin{array}{r}56 \\
144 \\
164 \\
10 \\
20\end{array}$ & $\begin{array}{l}5 \\
2 \\
2 \\
3\end{array}$ & $\begin{array}{l}4 \\
3 \\
2 \\
1\end{array}$ & $\begin{array}{l}\text { Alluvium } \\
\text { Alluvium } \\
\text { Alluvium } \\
\text { Alluvium } \\
\text { Alluvium }\end{array}$ & $\begin{array}{l}595 \\
596 \\
597 \\
598 \\
599\end{array}$ & $\begin{array}{r}44 \\
10 \\
204 \\
140 \\
196\end{array}$ & $\begin{array}{l}5 \\
3 \\
5 \\
1 \\
7\end{array}$ & $\begin{array}{l}3 \\
3 \\
4 \\
8 \\
4\end{array}$ & $\begin{array}{l}\text { Alluvium } \\
\text { Alluvium } \\
\text { Fault gouge } \\
\text { Carbonate vein } \\
\text { Carbonate vein }\end{array}$ \\
\hline $\begin{array}{l}501 \\
502 \\
504 \\
505 \\
506\end{array}$ & $\begin{array}{l}264 \\
180 \\
300 \\
196 \\
480\end{array}$ & $\begin{array}{l}5 \\
2 \\
5 \\
4 \\
5\end{array}$ & $\begin{array}{l}6 \\
6 \\
4 \\
8 \\
6\end{array}$ & $\begin{array}{l}\text { Alluvium } \\
\text { Alluvium } \\
\text { Alluvium } \\
\text { Alluvium } \\
\text { Shale }\end{array}$ & $\begin{array}{l}600 \\
601 \\
602 \\
603 \\
605\end{array}$ & $\begin{array}{r}120 \\
128 \\
68 \\
122 \\
1,280\end{array}$ & $\begin{array}{l}5 \\
3 \\
7 \\
2 \\
2\end{array}$ & $\begin{array}{l}3 \\
3 \\
4 \\
1 \\
1.5\end{array}$ & $\begin{array}{l}\text { Alluvium } \\
\text { Alluvium } \\
\text { Shale } \\
\text { Alluvium } \\
\text { Sandstone }\end{array}$ \\
\hline $\begin{array}{l}507 \\
508 \\
510 \\
512 \\
514\end{array}$ & $\begin{array}{r}920 \\
>4,000 \\
372 \\
1,000 \\
520\end{array}$ & $\begin{array}{l}3 \\
2 \\
5 \\
5 \\
9\end{array}$ & $\begin{array}{l}4 \\
6 \\
4 \\
4 \\
3\end{array}$ & $\begin{array}{l}\text { Alluvium } \\
\text { Alluvium } \\
\text { Alluvium } \\
\text { Shale, sheared } \\
\text { Carbonate vein }\end{array}$ & $\begin{array}{l}608 \\
609 \\
610 \\
611 \\
613\end{array}$ & $\begin{array}{r}136 \\
20 \\
36 \\
160 \\
60\end{array}$ & $\begin{array}{l}2 \\
0.5 \\
3 \\
3 \\
17\end{array}$ & $\begin{array}{l}3 \\
1 \\
2 \\
2 \\
4\end{array}$ & $\begin{array}{l}\text { Alluvium } \\
\text { Sandstone } \\
\text { Alluvitm } \\
\text { Sandstone } \\
\text { Carbonate vein }\end{array}$ \\
\hline $\begin{array}{l}515 \\
516 \\
517 \\
518 \\
520\end{array}$ & $\begin{array}{r}>4,000 \\
660 \\
260 \\
230 \\
220\end{array}$ & $\begin{array}{l}7 \\
3 \\
3 \\
2 \\
5\end{array}$ & $\begin{array}{l}6 \\
6 \\
4 \\
4 \\
6\end{array}$ & $\begin{array}{l}\text { Alluvium } \\
\text { Alluvium } \\
\text { Fault gouge } \\
\text { Alluvium } \\
\text { Alluvium }\end{array}$ & $\begin{array}{l}614 \\
615 \\
616 \\
619 \\
620\end{array}$ & $\begin{array}{r}90 \\
145 \\
225 \\
65 \\
68\end{array}$ & $\begin{array}{l}3 \\
5 \\
2 \\
2 \\
2\end{array}$ & $\begin{array}{l}4 \\
4 \\
1.5 \\
2 \\
4\end{array}$ & $\begin{array}{l}\text { Alluvium } \\
\text { Alluvium } \\
\text { Shale } \\
\text { Alluvium } \\
\text { Shale }\end{array}$ \\
\hline $\begin{array}{l}521 \\
522 \\
523 \\
525 \\
530\end{array}$ & $\begin{array}{r}720 \\
1,100 \\
36 \\
24 \\
20\end{array}$ & $\begin{array}{l}5 \\
2 \\
5 \\
1 \\
1\end{array}$ & $\begin{array}{l}4 \\
3 \\
3 \\
< \\
0.5 \\
2\end{array}$ & $\begin{array}{l}\text { Alluvium } \\
\text { Alluvium } \\
\text { Alluvium } \\
\text { Alluvium } \\
\text { Alluvium }\end{array}$ & $\begin{array}{l}701 \\
702 \\
703 \\
704 \\
6010\end{array}$ & 24 & $\begin{array}{l}3 \\
3 \\
5 \\
5\end{array}$ & $\begin{array}{l}8 \\
3 \\
6 \\
6\end{array}$ & $\begin{array}{l}\text { Alluvium } \\
\text { Carbonate vein } \\
\text { Alluvium } \\
\text { Alluvium } \\
\text { Sandstone }\end{array}$ \\
\hline $\begin{array}{l}532 \\
535 \\
536 \\
537 \\
538\end{array}$ & $\begin{array}{l}10 \\
24 \\
16 \\
12 \\
36\end{array}$ & $\begin{array}{l}0.5 \\
3 \\
1 \\
1 \\
3\end{array}$ & $\begin{aligned} & 4 \\
& 2 \\
& 2 \\
& 1 \\
&< 0.5\end{aligned}$ & $\begin{array}{l}\text { Conglomerate } \\
\text { Alluvium } \\
\text { Alluvium } \\
\text { Sedimentary rock } \\
\text { Sedimentary rock }\end{array}$ & $\begin{array}{l}6020 \\
6030 \\
6040 \\
6050 \\
6060\end{array}$ & $\begin{array}{l}28 \\
36 \\
48 \\
28 \\
40\end{array}$ & & & $\begin{array}{l}\text { Sandstone } \\
\text { Sandstone } \\
\text { Sandstone } \\
\text { Sandstone } \\
\text { Sand stone }\end{array}$ \\
\hline $\begin{array}{l}539 \\
541 \\
543 \\
544 \\
545\end{array}$ & $\begin{array}{l}10 \\
44 \\
36 \\
88 \\
20\end{array}$ & $\begin{array}{l}1 \\
5 \\
3 \\
9 \\
7\end{array}$ & $\begin{array}{l}<0.5 \\
6 \\
6 \\
3 \\
4\end{array}$ & $\begin{array}{l}\text { Limestone } \\
\text { Siltstone } \\
\text { Siltstone } \\
\text { Siltstone } \\
\text { Siltstone }\end{array}$ & $\begin{array}{l}6070 \\
6080 \\
6090 \\
6100 \\
6110\end{array}$ & $\begin{array}{l}24 \\
20 \\
24 \\
16 \\
16\end{array}$ & & & $\begin{array}{l}\text { Sandstone } \\
\text { Siltstone } \\
\text { Sandstone } \\
\text { Sandstone } \\
\text { Sandstone }\end{array}$ \\
\hline $\begin{array}{l}546 \\
547 \\
548 \\
549 \\
550\end{array}$ & $\begin{array}{l}10 \\
12 \\
12 \\
10 \\
52\end{array}$ & $\begin{array}{l}2 \\
1 \\
2 \\
0.5 \\
3\end{array}$ & $\begin{aligned}< & 0.5 \\
< & 0.5 \\
& 1.5 \\
& 2 \\
& 1.5\end{aligned}$ & $\begin{array}{l}\text { Sandstone } \\
\text { Sandstone } \\
\text { Conglomerate } \\
\text { Conglomerate } \\
\text { Siltstone }\end{array}$ & $\begin{array}{l}6130 \\
6150 \\
6160 \\
6170 \\
6180\end{array}$ & $\begin{array}{r}44 \\
96 \\
16 \\
160 \\
620\end{array}$ & & & $\begin{array}{l}\text { Sandstone } \\
\text { Sand stone } \\
\text { Sand stone } \\
\text { Sand stone } \\
\text { Sand st one }\end{array}$ \\
\hline $\begin{array}{l}552 \\
554 \\
555 \\
557 \\
558\end{array}$ & $\begin{array}{r}36 \\
24 \\
24 \\
368 \\
188\end{array}$ & $\begin{array}{r}7 \\
2 \\
2 \\
11 \\
4\end{array}$ & $\begin{array}{l}3 \\
4 \\
6 \\
8 \\
1\end{array}$ & $\begin{array}{l}\text { Siltstone } \\
\text { Shale } \\
\text { Shale } \\
\text { Shale } \\
\text { Siltstone }\end{array}$ & $\begin{array}{l}6190 \\
6200 \\
6210 \\
6220 \\
6230\end{array}$ & $\begin{array}{l}60 \\
36 \\
24 \\
44 \\
52\end{array}$ & & & $\begin{array}{l}\text { Sand stone } \\
\text { Sand stone } \\
\text { Sandstone } \\
\text { Shale } \\
\text { Sandstone }\end{array}$ \\
\hline $\begin{array}{l}559 \\
560 \\
561 \\
563 \\
564\end{array}$ & $\begin{array}{r}96 \\
660 \\
72 \\
52 \\
84\end{array}$ & $\begin{array}{r}11 \\
9 \\
2 \\
3 \\
2\end{array}$ & $\begin{array}{l}4 \\
1 \\
3 \\
3 \\
2\end{array}$ & $\begin{array}{l}\text { Siltstone } \\
\text { Shale, organic } \\
\text { Alluvium } \\
\text { Shale } \\
\text { Alluvium }\end{array}$ & $\begin{array}{l}6240 \\
6250 \\
6260 \\
6270 \\
6280\end{array}$ & $\begin{array}{l}28 \\
28 \\
28 \\
24 \\
48\end{array}$ & & & $\begin{array}{l}\text { Sandstone } \\
\text { Sandstone } \\
\text { Sandstone } \\
\text { Siltstone } \\
\text { Siltstone }\end{array}$ \\
\hline $\begin{array}{l}566 \\
567 \\
568 \\
569 \\
570\end{array}$ & $\begin{array}{r}52 \\
24 \\
180 \\
188 \\
24\end{array}$ & $\begin{array}{l}3 \\
3 \\
3 \\
2 \\
3\end{array}$ & $\begin{array}{l}4 \\
1.5 \\
1 \\
2 \\
4\end{array}$ & $\begin{array}{l}\text { Shale } \\
\text { Sand stone } \\
\text { Alluvium } \\
\text { Sand stone } \\
\text { Alluvium }\end{array}$ & $\begin{array}{l}6290 \\
6300 \\
6310 \\
6320 \\
6340\end{array}$ & $\begin{array}{r}40 \\
80 \\
44 \\
2,320 \\
1,880\end{array}$ & & & $\begin{array}{l}\text { Sandstone } \\
\text { Siltstone } \\
\text { Siltstone } \\
\text { Sandstone } \\
\text { Sandstone }\end{array}$ \\
\hline $\begin{array}{l}571 \\
572 \\
573 \\
574 \\
575\end{array}$ & $\begin{array}{r}52 \\
120 \\
28 \\
112 \\
60\end{array}$ & $\begin{array}{l}3 \\
2 \\
3 \\
3 \\
9\end{array}$ & $\begin{array}{l}1 \\
4 \\
3 \\
2 \\
8\end{array}$ & $\begin{array}{l}\text { Alluvium } \\
\text { Alluvium } \\
\text { Alluvium } \\
\text { Alluvium } \\
\text { Shale }\end{array}$ & $\begin{array}{l}6360 \\
6370 \\
6380 \\
6390 \\
6420\end{array}$ & $\begin{array}{r}1,160 \\
760 \\
660 \\
860 \\
16\end{array}$ & & & $\begin{array}{l}\text { Sand stone } \\
\text { Sand stone } \\
\text { Sandstone } \\
\text { Sand stone } \\
\text { Siltstone }\end{array}$ \\
\hline $\begin{array}{l}576 \\
577 \\
578 \\
580 \\
582\end{array}$ & $\begin{array}{r}112 \\
68 \\
72 \\
140 \\
96\end{array}$ & $\begin{array}{l}3 \\
7 \\
3 \\
7 \\
7\end{array}$ & $\begin{array}{l}4 \\
6 \\
6 \\
8 \\
6\end{array}$ & $\begin{array}{l}\text { Carbonate vein } \\
\text { Alluvium } \\
\text { Alluvium } \\
\text { Shale } \\
\text { Shale }\end{array}$ & $\begin{array}{l}6430 \\
6440 \\
6450 \\
6460 \\
6470\end{array}$ & $\begin{array}{l}20 \\
20 \\
28 \\
36 \\
16\end{array}$ & & & $\begin{array}{l}\text { Siltstone } \\
\text { Sand stone } \\
\text { Sand stone } \\
\text { Shale } \\
\text { Sandstone }\end{array}$ \\
\hline $\begin{array}{l}583 \\
584 \\
585 \\
586 \\
587\end{array}$ & $\begin{array}{r}76 \\
76 \\
212 \\
88 \\
44\end{array}$ & $\begin{array}{l}3 \\
3 \\
3 \\
7 \\
2\end{array}$ & $\begin{array}{l}4 \\
3 \\
6 \\
4 \\
4\end{array}$ & $\begin{array}{l}\text { Alluvium } \\
\text { Siltstone } \\
\text { Siltstone } \\
\text { Alluvium } \\
\text { Carbonate vein }\end{array}$ & $\begin{array}{l}6480 \\
6490 \\
6500 \\
6510 \\
6520\end{array}$ & $\begin{array}{l}24 \\
36 \\
16 \\
24 \\
10\end{array}$ & & & $\begin{array}{l}\text { Siltstone } \\
\text { Sand stone } \\
\text { Sand stone } \\
\text { Sand stone } \\
\text { Sand stone }\end{array}$ \\
\hline $\begin{array}{l}589 \\
590 \\
591 \\
592 \\
594\end{array}$ & $\begin{array}{r}36 \\
68 \\
84 \\
156 \\
88\end{array}$ & $\begin{array}{l}2 \\
2 \\
7 \\
9 \\
14\end{array}$ & $\begin{array}{l}2 \\
3 \\
1.5 \\
1.5 \\
4\end{array}$ & $\begin{array}{l}\text { Alluvium } \\
\text { Alluvium } \\
\text { Carbonate vein } \\
\text { Fault gouge } \\
\text { Fault gouge }\end{array}$ & $\begin{array}{l}6530 \\
6540 \\
6550 \\
6560\end{array}$ & $\begin{array}{l}12 \\
10 \\
10 \\
28\end{array}$ & & & $\begin{array}{l}\text { Sand st one } \\
\text { Sands tone } \\
\text { Sand st one } \\
\text { Sand st one }\end{array}$ \\
\hline
\end{tabular}


lying mercury ore deposits. Williston (1964, p. 100) shows a profile of mercury in soil over the Cordero mine, Nevada, on which the regional background appears to be less than $100 \mathrm{ppb}$, the local background within half a mile of the ore zone $90-900 \mathrm{ppb}$, and the peak of the anomaly over the ore zone more than $10,000 \mathrm{ppb}$.

Elsewhere, Ward and Bailey (1961) found local backgrounds of 5,000 ppb mercury or less in soil near two quicksilver ore bodies that occurred within 50 feet of the surface and noted values ranging from 3-50 times background in soil over the ore bodies. In contrast, the highest concentration found in the San Rafael primitive area is $3,300 \mathrm{ppb}$.

The rocks in the Cachuma district, in contrast to those in most of the primitive area, are cut by many small faults or shears that are filled with carbonate minerals. The median values for mercury in fault gouge and breccia and carbonate veins (table 2) is notably higher than those in undisturbed or unmineralized rocks. This relationship suggests that the introduction of carbonate minerals along the more permeable fault zones occurred more or less concurrently with mercury mineralization.

The rocks in Sulphur Spring Canyon are faulted and locally sheared. Springs issuing from these disturbed rocks have formed small deposits of travertine. Mercury vapor from a source at depth might have migrated up the more permeable fault zones in this area and then spread out through the fractured rock and sandstone beds. The relatively high mercury values discovered in sandstone here are apparently associated with faulted and structurally disturbed rocks, but none of the mercury or carbonate minerals that commonly accompany quicksilver ore bodies were noted.

TABLE 2.-Mercury content of rocks

[In parts per billion]

\begin{tabular}{l|r|r|r|r}
\hline & $\begin{array}{c}\text { Shale and } \\
\text { mudstone }\end{array}$ & $\begin{array}{c}\text { Conglomerate, } \\
\text { sandstone, and } \\
\text { siltstone }\end{array}$ & $\begin{array}{c}\text { Carbonate } \\
\text { vein } \\
\text { material }\end{array}$ & $\begin{array}{c}\text { Fault } \\
\text { gouge and } \\
\text { breccia }\end{array}$ \\
\hline Number of samples & 52 & 140 & 11 & 7 \\
Hg-range & $10-1,000$ & $<10-3,300$ & $45-520$ & $25-1,000$ \\
Hg-median & 40 & 40 & 75 & 225 \\
\hline
\end{tabular}

Although sandstone beds in the Sulphur Spring Canyon area contain anomalous amounts of mercury, the likelihood of nearsurface ore bodies is low because of the absence of carbonatealtered rock, mercury minerals, and the low mercury values in adjacent shale. Possibly the anomalous mercury values reflect the 


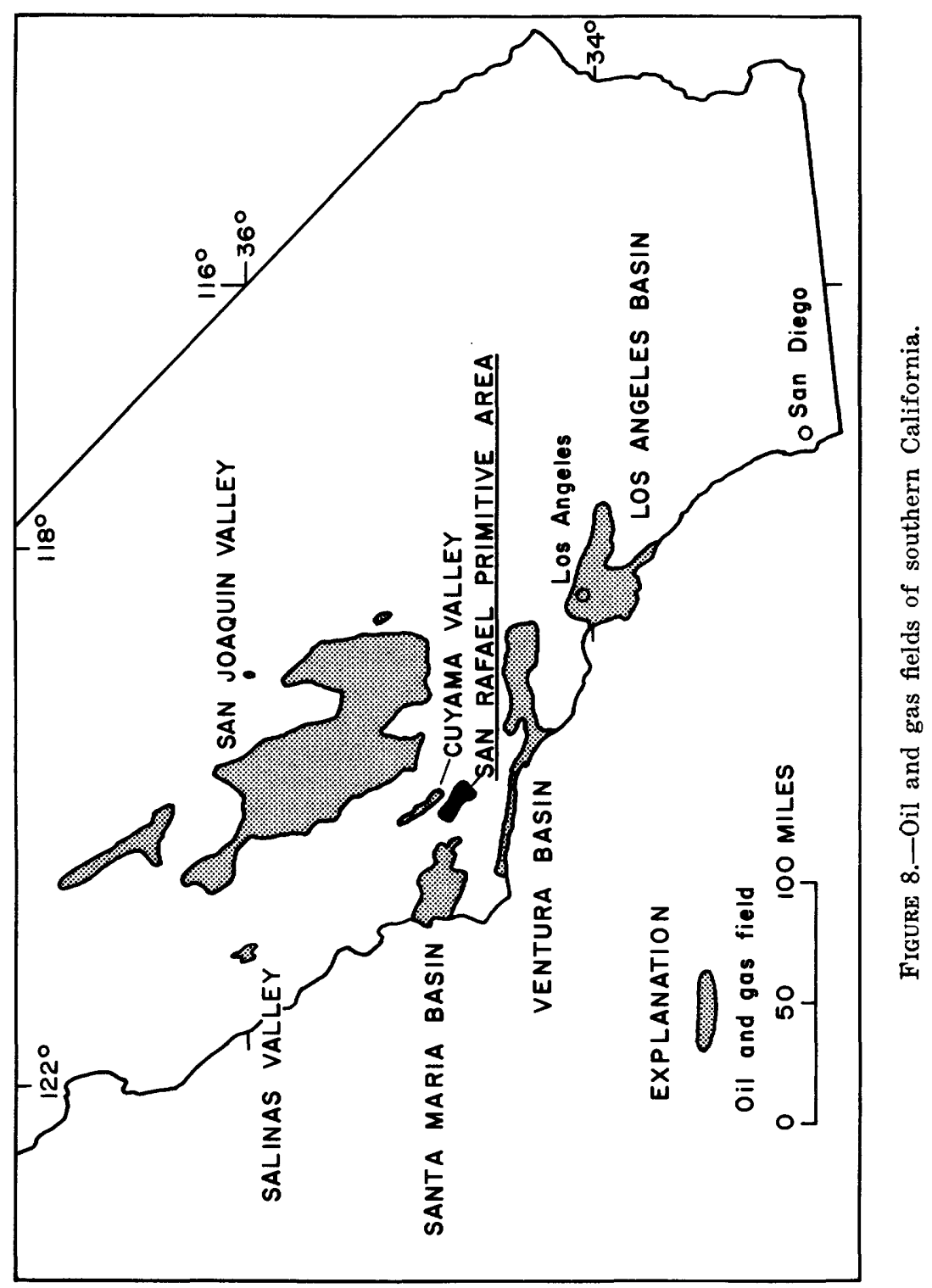


edge or margin of a mercury halo surrounding an ore body at depth, but the restricted extent of the anomalous values and the rather small size of the known quicksilver deposits of the Cachuma district make deep exploration for mercury in the primitive area economically unattractive. The possibility of discovering a quicksilver ore body in the San Rafael primitive area is considered low.

\section{PETROLEUM}

The San Rafael primitive area is flanked by producing oil fields in the Cuyama Valley, about 5 miles north of the area, in the Santa Maria basin, about 10 miles to the west, and in the Ventura basin, about 25 miles to the southeast (fig. 8). The area itself is underlain by a thick section of marine sedimentary rocks. Although some petroleum and natural gas may be present, the petroleum potential is believed to be poor. About 75 percent of the area is underlain by Upper Cretaceous and Eocene rocks; only a minor amount of petroleum has been removed from rocks of these ages in nearby areas. The other 25 percent of the area is underlain by rocks of Miocene age, which have been prolific sources of petroleum in many places in southern California, including the Cuyama Valley. Within the primitive area, however, the Miocene rocks are thin (except in the Hurricane Deck syncline) and contain relatively small potential structural and stratigraphic traps.

There is no record of exploratory drilling within the primitive area; only two (possibly three) leases for small acreage were issued before the withdrawal of a fairly large part of the area. The leases were not drilled, possibly because of the rough terrain and limited access roads. Several test holes in adjacent areas penetrated strata that might occur in the subsurface in the primitive area. Two wells tested Miocene and Lower(?) Cretaceous rocks within 2-3 miles of the southwest border of the area, and about half a dozen wells tested Miocene, Eocene, and possibly Cretaceous rocks in limited areas 2-3 miles north and northeast of the area. These wells were not productive, but very minor amounts of petroleum were present in Miocene and possibly older rocks in some of these wells (Jennings and Hart, 1953; California State Oil and Gas Supervisor, 1964).

The largest of the possible structural traps for petroleum in the primitive area is the Mission Pine anticline. This broad eastplunging fold is cut by several north-trending cross faults and terminates against a branch of the Big Pine fault near McKinley Mountain, just outside the western border of the primitive area. Possible entrapment of petroleum could take place next to the fault near McKinley Mountain or along any of the cross faults that cut 
the crest of the fold. This large structure involves only Cretaceous rocks, which have not been productive but which have been very little tested in nearby areas (Conserv. Comm. California Oil Producers, 1961, 1965).

The Cretaceous rocks are also folded into several anticlines between the Hurricane Deck syncline and the Nacimiento( ?) fault, but these folds are all small (1-11/2 miles long) and lack apparent structural closure; therefore, they are of questionable value as potential trap structures. Similarly, Eocene strata are folded into several small anticlines north of the Sisquoc River, but these structures also appear to lack closure. All other potential traps are relatively small stratigraphic or fault traps involving Miocene rocks on the north limb of the Hurricane Deck syncline. West of Miller Canyon the west-trending fault separating Miocene and Cretaceous rocks could form trap structures by bringing south-dipping Miocene sandstone against impermeable Cretaceous strata on the north. Stratigraphic relations suggest that the Miocene sandstone lenses wedge out into claystone from south to north across the axis of this syncline and thus could form stratigraphic traps on the north limb of this fold.

Although the primitive area contains both potential petroleum trap structures and reservoir rocks, these two geologic prerequisites occur together only on a small scale in Miocene rocks on the north limb of the Hurricane Deck syncline. Even there the existence of petroleum accumulations is doubtful because most of the potential reservoir rocks lie above the drainage level of the Sisquoc River. The petroleum potential of the Cretaceous rocks, even in the Mission Pine anticline, must be considered low, because of the lack of production from rocks of this age in nearby oil fields. Rocks of Eocene age have been a minor source of petroleum in this region (Conserv. Comm. California Oil Producers, 1961, 1965), but in the primitive area, rocks of this age lack well-defined trap structures and seem to have low porosities and permeabilities. Several drill holes have tested Eocene rocks 2-3 miles northeast of the primitive area without success.

\section{LIMESTONE}

Some parts of the Sierra Blanca Limestone of Nelson (1925) that crop out in the southeastern part of the primitive area meet the specifications designated for cement rock and other types of commercial limestone. This limestone unit was investigated and its economic possibilities appraised in the area near the Big Pine Mountain road and eastward by Walker (1950), who noted that its inaccessibility as compared with other limestone deposits in the region had deterred attempts to establish commercial quarry- 
ing operations. The Sierra Blanca Limestone of Nelson (1925) crops out principally in a belt that extends about a mile northwest into the San Rafael primitive area from the Big Pine Mountain road. In this belt, which is several hundred feet wide, the limestone is about 100-200 feet thick. Locally, the limestone contains abundant clay matrix, but the upper 70-80 feet consists of relatively pure limestone. A sample collected by Walker along the Big Pine Mountain road contained 94.76 percent $\mathrm{CaCO}_{3}$ (table 3). Four samples collected by Keenan (1932) about 2 miles east of the area along Indian Creek range from 90.60 to 98.80 percent $\mathrm{CaCO}_{3}$.

TABLE 3.-Partial analysis of Sierra Blanca Limestone of Nelson (1925) ${ }^{1}$

\begin{tabular}{|c|c|c|c|}
\hline \multicolumn{3}{|c|}{ Percent } & Percent \\
\hline $\mathrm{CaCO}_{3}$ & n-n & $\mathrm{Al}_{2} \mathrm{O}_{3}$ & 0.37 \\
\hline $\mathrm{CaO}$ & - & $\mathrm{Fe}_{2} \mathrm{O}_{3}$ & .33 \\
\hline $\mathrm{MgO}$ & - - - & - n- & 2.01 \\
\hline
\end{tabular}

'Analyzed by P. T. Bee, Chief Chemist, Abbot A. Hanks, Inc., San Francisco, Calif. Represents composite grab sample of highest grade part of Sierra Blanca Limestone of Nelson (1925) collected at 2- to 3-foot intervals in cuts along Big Pine Road about 41/2 miles north of Little Pine Mountain. Interval sampled represents stratigraphic thickness of 70-80 feet. From Walker $(1950$, p. 5).

Near the Big Pine fault, the Sierra Blanca crops out in a narow discontinuous belt that is parallel to the part of the fault zone lying between the east edge of the area and Grapevine Creek. It is exposed again farther south, on the south limb of a small syncline extending about half a mile east and west of Grapevine Creek. In both localities it is on steep slopes heavily mantled with overburden. Most of the exposures in this area are impure clastic limestone, but the exposures are poor and the average quality of the limestone is uncertain. Two examples were collected along the Grapevine Trail about a mile west of the east border of the area. One, a white pure algal limestone contained 0.61 percent insoluble residue; the other, a somewhat impure medium-gray algal limestone, contained 5.03 percent.

Although parts of the Sierra Blanca Limestone of Nelson (1925) are compositionally similar to limestones used commercially, the limestone within the San Rafael primitive area would seem to be too unfavorably located to warrant mining.

\section{OTHER COMMODITIES INVESTIGATED}

Stream sediments in the primitive area and the adjacent Cachuma quicksilver district were sampled and analyzed for copper and other heavy metals (principally zinc and lead) by coldacid-extractable copper and citrate-soluble heavy-metal tests (Ward and others, 1963, p. 25-29). The locations of samples are 
shown on plate 2 , and the base-metal values found at each locality are given in table 1. The concentrations of copper and other heavy metals are all low. The highest values occur along Manzana Creek near the southwestern border of the primitive area and in the Cachuma district outside the primitive area. Even in these areas, the highest values are only about three times the median value (table 4) and seem to indicate only that trace amounts of these metals are present in areas where mercury is relatively abundant. No evidence of a base-metal deposit was found in the primitive area.

TABLE 4.--Base-metal content of stream sediment

[In parts per million]

\begin{tabular}{l|c|c|c}
\hline & $\begin{array}{c}\text { Number } \\
\text { of samples }\end{array}$ & Range & Median \\
\hline Citrate-soluble heavy metals & 101 & $<0.5-7$ & 2 \\
Cold-acid-extractable copper & 102 & $<.5-8$ & 3 \\
\hline
\end{tabular}

Phosphate deposits of potential commercial value occur in siliceous sedimentary rocks of Miocene age in several places in the southern Coast Ranges (Gower and Madsen, 1964). Three principal horizons of maximum phosphate concentration have been recognized in this region, one at the top of the middle Miocene and two in the upper Miocene. No strata of late Miocene age occur in the primitive area. A thick section of siliceous rocks of middle Miocene age is present in several places, but the top of this sequence, which elsewhere contains the main phosphate horizon, has apparently been removed by erosion. Well-exposed sections of siliceous shale were examined in detail on the south limb of the Hurricane Deck syncline and south of the Hildreth fault, but only a few scattered phosphate nodules $1 / 4-1$ inch long were seen. There is little possibility of a commercial deposit of phosphate within the primitive area.

The southern Coast Ranges contain the most extensive commercial deposits of diatomite in the world (Oakeshott, 1957, p. 183). The principal deposits occur in the vicinity of Lompoc, 15-25 miles southwest of the primitive area, in marine shales of late Miocene and early Pliocene age. No rocks of that age are present in the primitive area, and there is little possibility of commercial deposits of diatomite being found there.

Gypsum deposits occur in several places in the southern Coast Ranges, but they were not found in the primitive area. The nearest deposits are in the vicinity of Santa Barbara and Quatal Canyons, 8-16 miles northeast of the primitive area. At these localities the 
best grade gypsum beds occur in rocks of late Miocene or Pliocene age (Ver Planck, 1957, p. 233). In that same area low-grade gypsiferous beds of doubtful commercial value occur in middle Miocene red beds. Neither upper Miocene strata nor middle Miocene redbed facies are present in the primitive area, and the possibility that commercial deposits of gypsum exist in the area is negligible.

\section{REFERENCES CITED}

Arnold, Ralph, and Anderson, Robert, 1907, Geology and oil resources of the Santa Maria oil district, Santa Barbara County, California: U.S. Geol. Survey Bull. 322, $161 \mathrm{p}$.

California State Oil and Gas Supervisor, 1964, Exploratory wells drilled outside of oil and gas fields in California to Dec. 31, 1963: California Div. Oil and Gas.

Conservation Committee of California Oil Producers, 1961, Annual Review of California Crude Oil Production, 1960: [Los Angeles, Calif.] variously paged.

-_ 1965, Annual Review of California Crude Oil Production, 1964: [Los Angeles, Calif.] variously paged.

Crowell, J. C., 1962, Displacement along the San Andreas fault, California: Geol. Soc. America Spec. Paper 71, 61 p.

Dibblee, T. W., Jr., 1950, Geology of southwestern Santa Barbara County, California-Point Arguello, Lompoc, Point Conception, Los Olivos, and Gaviota quadrangles: California Div. Mines Bull. 150, 95 p.

Everhart, D. L., 1950, Quicksilver deposits of the Cachuma district, Santa Barbara County; California: California Jour. Mines and Geology, v. 46, no. 4, p. 509-532.

Fairbanks, H. W., 1894, Geology of northern Ventura, Santa Barbara, San Luis Obispo, Monterey, and San Benito Counties: California State Mining Bur., 12th Ann. Rept. State Mineralogist, p. 493-526.

Gower, H. D., and Madsen, B. M., 1964, The occurrence of phosphate rock in California: U.S. Geol. Survey Prof. Paper 501-D, p. D79-D85.

Hill, M. L., and Dibblee, T. W., Jr., 1953, San Andreas, Garlock and Big- Pine faults, California: Geol. Soc. America Bull., v. 64, p. 443-458.

Jennings, C. W., 1959, Geologic map of California, San Luis Obispo sheet: California Div. Mines, scale 1:250,000.

Jennings, C. W., and Hart, E. W., 1953, Exploratory wells drilled outside of oil and gas fields in California to December 31, 1953: California Div. Mines Spec. Rept. 45, 104 p.

Keenan, M. F., 1932, The Eocene Sierra Blanca Limestone at the type locality in Santa Barbara County, California: San Diego Soc. Nat. History Trans., v. 7, no. 8, p. 53-84.

Kew, W. S. W., 1919, Geology of a part of the Santa Ynez River district, Santa Barbara County, California: California Univ., Dept. Geology Bull., v. 12 , no. 1,21 p.

Kundert, C. J., 1955, Geologic map of California, Los Angeles sheet: California Div. Mines, scale 1:250,000.

Nelson, R. N., 1925, Geology of the hydrographic basin of the upper Santa Ynez River, California: California Univ., Dept. Geol. Sci. Bull., v. 15, no. 10, p. 327-396.

Oakeshott, G. B., 1957, Diatomite, in California Div. Mines, Mineral commodities of California***: California Div. Mines Bull. 176, p. 183-193. 
Reed, R. D., and Hollister, J. S., 1936, Structural evolution of southern California: Tulsa, Okla., Am. Assoc. Petroleum Geologists, 157 p.; also pub. as: Am. Assoc. Petroleum Geologists Bull., v. 20, no. 12, p. 15291704, Dec. 1936.

Vaughn, W. W., and McCarthy, J. H., Jr., 1964, An instrumental technique for the determination of submicrogram concentrations of mercury in soils, rocks, and gas: U.S. Geol. Survey Prof. Paper 501-D, p. D123-D127.

Ver Planck, W. E., 1957, Gypsum, in California Div. Mines, Mineral commodities of California***: California Div. Mines Bull. 176, p. 231-240.

Walker, G. W., 1950, Sierra Blanca Limestone in Santa Barbara County, California: California Div. Mines Spec. Rept. 1-A, 5 p.

Ward, F. N., and Bailey, E. H., 1961, Camp and sample-site determination of traces of mercury in soils and rocks: Am. Inst. Mining Metall. Petroleum Engineers Trans. 1960, v. 217, p. 343-350.

Ward, F. N., Lakin, H. W., Canney, F. C., and others, 1963, Analytical methods used in geochemical exploration by the U.S. Geological Survey: U.S. Geol. Survey Bull. 1152, 100 p.

Williston, S. H., 1964, The mercury halo method of exploration: Eng. and Mining Jour., v. 165 , no. 5, p. 98-101. 